\title{
DAMPAK USAHATANI KOMODITAS PORANG TERHADAP KESEJAHTERAAN MASYARAKAT DI DESA KLANGON, KECAMATAN SARADAN, KABUPATEN MADIUN
}

\author{
Risky Al Hamdhan
}

Prodi Ilmu Ekonomi, Fakultas Ekonomi dan Bisnis Islam, UIN Sunan Ampel Surabaya

\begin{abstract}
Abstrak
Porang menjadi komoditi ekspor unggulan Desa Klangon Kecamatan Saradan Kabupaten Madiun. Tanaman porang memiliki harga jual yang tinggi dan merupakan komoditi utama sebagai salah satu sumber pendapatan daerah, serta kemakmuran masyarakat. Penelitian ini bertujuan untuk mendeskripsikan dampak usahatani komoditas porang terhadap kesejahteraan masyarakat yang dilihat dari kelembagaan dan biaya produksi, pemasaran dan penerimaan serta pendapatan petani. Objek lokasi penelitian dipilih berdasarkan pertimbangan bahwasannya Desa Klangon merupakan sentral produsen porang di Kabupaten Madiun dan sekaligus endemik porang Indonesia yang diberi dengan Madiun-1. Hasil penelitian mengungkapkan bahwa, ditinjau dari tingkat kesejahteraan rakyat di Desa Klangon ini mayoritas pada tingkat level sedang, dengan persentase $40,9 \%$ atau sebanyak $738 \mathrm{KK}$ yang dalam kriteria menengah keatas. Dengan menggunakan analisis data deskriptif kualitatif melalui proses reduksi data dan perhitungan, maka produksi awal (investasi awal) usahatani porang dengan luas lahan satu hektar dengan biaya Rp.87.660.000, rata-rata pendapatan pertahun yang diperoleh petani ialah Rp.260.340.000. Melihat potensi dan besarnya keuntungan dalam budidaya porang terhadap kesejahteraan masyarakat desa, untuk itu perlu adanya campur tangan Pemerintah Kabupaten Madiun guna melakukan pemilihan lokasi baru untuk budidaya porang. Serta perlu adanya peningkatan investasi pada komoditas tersebut karena mengingat masih sangat mungkin untuk ditingkatkan.
\end{abstract}

Kata kunci: porang, klangon, kesejahteraan masyarakat, analisis usahatani

\begin{abstract}
Porang is the leading export commodity in Klangon Village, Saradan District, Madiun Regency. The porang plant has a high selling price and is the main commodity as a source of regional income, as well as the people's welfare. This study aims to describe the impact of porang commodity farming on community welfare as seen from the institutional and production costs, marketing and income and farmer income. The object of the research location was chosen based on the consideration that Klangon Village is the central producer of porang in Madiun Regency and at the same time is endemic to Indonesian porang given Madiun-1. The results of the study reveal that, in terms of the welfare level of the people in Klangon Village, the majority are at the medium level, with a percentage of 40, 9\% or as many as 738 households in the upper middle criteria. By using qualitative descriptive data analysis through the process of data reduction and calculation, the initial production (initial investment) of porang farming with a land area of one hectare at a cost of Rp. 87,660,000, the average annual income earned by farmers is Rp. 260,340,000. Seeing the potential and the magnitude of the benefits in cultivating porang for the welfare of the village community, it is necessary for the Madiun Regency Government to intervene in selecting a new location for porang cultivation. And there needs to be an increase in investment in these commodities because it is still possible to increase it.
\end{abstract}

Keywords: porang, klangon, community walfare, economic analysis of farming 


\section{Pendahuluan}

Guna menopang perekonomian Indonesia, sektor pertanian menjadi salah satu opsi yang perlu pemfokusan untuk pengembangan. Sektor ini merupakan resources based, hal ini ditinjau dari pangsa sektor pertanian yang cukup besar terhadap Produk Domestik Bruto (PDB). Berdasarkan hal tersebut, seharusnya sektor ini mendapat perhatian yang lebih dominan dibandingkan dengan sektor industri.

Komoditas sub-sektor pertanian yang cukup menonjol di Jawa Timur ialah komoditas porang. Tamanan porang pada beberapa tahun terakhir ini menjadi populer karena tanaman ini toleran naungan, mudah dibudidayakan, mempunyai produktivitas yang tinggi, hama atau penyakit yang menyerang relatif sedikit, permintaan pasar meningkat dan mempunyai nilai ekonomi yang tinggi yaitu sebagai penyedia lapangan kerja baru, pendapatan daerah, dan perolehan devisa baik ekspor maupun produk olahannya. Prospek dari komoditas ini bisa dibilang memang sangat menjanjikan karena memiliki nilai ekonomi terutama untuk industri dan kesehatan (Faridah, et al., 2012). Pasalnya dilihat dari segi ekonomi, tanaman porang ini lebih menguntungkan dan cepat mendapatkan hasil dengan kata lain hasil yang didapat sangat tinggi dibanding komoditas pertanian lainnya seperti padi, kopi, karet, tebu, dll.

Kabupaten Madiun merupakan salah satu kabupaten yang ada di Provinsi Jawa Timur yang memiliki potensi sumberdaya alam berupa lahan hutan. Kabupaten Madiun memiliki kawasan hutan negara kurang lebih $40.631 \mathrm{Ha}$, sedangkan kawasan peruntukan hutan rakyat di Kabupaten Madiun mencapai luas kurang lebih 5.821 Ha. Dengan luas wilayah tersebut dimungkinkan sangat berpotensi untuk diadakan pemetakan luasan lahan tegakan dalam upaya pemberdayaan budidaya porang.

Porang dalam bahasa ilmiahnya yaitu Amorphophallus oncophyllus Prain merupakan tanaman penghasil umbi dan merupakan salah satu kekayaan hayati umbi-umbian Indonesia yang dapat dimakan dan penampilannya sekilas mirip seperti suweg, walur, iles-iles sehingga yang menjadi pembeda ialah pada tanaman porang terdapat bubil/katak pada setiap pertemuan cabang dan ketiak daun. Porang sebagai tanaman penghasil karbohidrat, lemak, protein, mineral, vitamin dan serat pangan sehingga tanaman ini sudah lama dimanfaatkan untuk bahan pangan dan diekspor sebagai bahan baku industri. Sebetulnya sejak Perang Dunia II, porang telah diekspor ke Jepang, Taiwan, Singapura dan Korea Selatan. Namun selanjutnya budidaya porang kurang berkembang. Pada tahun 1875-an, usahatani porang kembali bergairah dengan adanya kenyataan bahwa tanaman tersebut bernilai ekonomis tinggi dan sangat menguntungkan petani karena glukomanannya dapat dimanfaatkan sebagai bahan pangan fungsional yang berkhasiat bagi kesehatan.

Menurut Ramdani Sari, et al. (2015) menyatakan bahwa sifat tanaman porang yang toleran terhadap naungan, memungkinkan tanaman ini dibudidayakan di lahan hutan dibawah naungan pohon jati, sonokeling, mahoni ataupun sengon. Jansen, et al. (1996) dalam purwanto (2014) menjelaskan bahwa untuk mencapai produktivitas umbi yang tinggi diperlukan naungan 50-60\%. Tanaman ini dapat tumbuh dengan baik di tempat dengan ketinggian 200-700 dpl dan curah hujan 300-500 mm pertahun selama periode pertumbuhan. Pada tahun 1980-an Perum Perhutani KPH Saradan, melalui program Pengelolaan Hutan Bersama Masyarakat (PHBM), bekerjasama dengan Masyarakat Desa Hutan (MDH) mulai mengembangkan tanaman porang di lahan tegakkan hutan yang dikelolanya dan salah satunya ialah berada di Desa Klangon. Desa Klangon menjadi sentral penghasil porang di Kabupaten Madiun. Wilayah ini terletak di Kaki Gunung Pandan, sehingga desa ini sangat cocok untuk pertumbuhan vegetatif dan generatif tanaman porang. Dahulunya desa klangon ini merupakan Desa IDT (Inpres Desa Tertinggal) atau ketegori desa miskin. Namun ternyata setelah adanya budidaya porang ini dapat meningkatkan ekonomi masyarakat desa. Budidaya komoditas 
porang dimulai pada tahun 1985. Tetapi hanya ada beberapa orang karena masyarakat belum mengetahui bahwa porang itu benar-benar menghasilkan dan kualitasnya baik. Barulah pada tahun 2010, masyarakat Desa Klangon mulai kompak membudidayakan dan sekarang 95\% masyarakat bermata pencaharian sebagai petani porang. Dengan kondisi diatas menunjukkan bahwasanya pengembangan budidaya dan pemanfaatan porang ke depan sangat prospektif karena lahan untuk budidaya tersedia, terutama di kawasan hutan sehingga tidak perlu bersaing dengan lahan komoditas tanaman pangan lainnya.

Komoditas porang menjadi komoditas ekspor unggulan Pemerintah Kabupaten Madiun. Mengacu pada beberapa tahun terakhir kebutuhan porang sangat besar yang ditandai dengan jumlah permintaan ekspor Indonesia akan porang tahun 2020 mencapai 11.170 ton. Di Kabupaten Madiun produksi porang pada tahun 2019 hanya sekitar 9.060,15 ton, meningkat sebesar 310,2 ton dibandingkan dengan tahun 2018. Menurut Kusnul Rofil, et al., (2017) keunggulan porang adalah digunakan untuk perekat kertas, mengkilapkan kain, cat kain katun dan tepungnya dapat dipergunakan sebagai bahan pengganti agar-agar, sebagai bahan pembuat negative flem, isolator dan seluloid. Sedangkan untuk larutannya bila dicampur dengan gliserin atau natrium hidroksida dapat digunakan untuk menjernihkan air dan memurnikan bagian-bagian keloid yang terapung dalam industri bir, gula, minyak dan serat. Porang juga dapat dijadikan sebagai bahan makanan khas masyarakat Jepang seperti mie shirataki, atau tahu konyaku.

Usahatani tamanan porang merupakan komoditi utama sebagai salah satu sumber pendapatan daerah, serta kemakmuran masyarakat. Pengembangan usahatani ini hakekatnya adalah untuk pembangunan ekonomi yang berorientasi terhadap pedesaan dengan sasarannya yaitu untuk meningkatkan pendapatan masyarakat desa dan untuk tujuan akhir mengurangi jumlah penduduk miskin di pedesaan, sekaligus bisa membuka lapangan kerja baru. Berdasarkan uraian diatas, dapat disimpulkan bahwasanya sub-sektor pertanian komoditas tanaman porang mempunyai keunggulan dan peran yang cukup besar dalam perekonomian desa terutama dalam meningkatkan kesejahteraan masyarakat di Desa Klangon, sebagai sentral penghasil porang di Kabupaten Madiun. Sedangkan untuk kelemahan dalam pengembangan porang di berbagai daerah selama ini menurut Iza Ari Arafia, et al.(2020) ialah kurangnya informasi sistem pemasaran porang dan terdapat beberapa kendala diantaranya mencakup pola pemasaran yang digunakan dan burgaining position dengan mitranya. Sehingga adapun tujuan penelitian ini ialah untuk mengetahui dampak usahatani komoditas porang terhadap kesejahteraan masyarakat di Desa Klangon, Kecamatan Saradan, Kabupaten Madiun, yang dilihat dari kelembagaan dan biaya produksi, pemasaran dan penerimaan serta pendapatan petani.

\section{Metode Penelitian}

Penelitian dilakukan di Desa Klangon, Kecamatan Saradan, Kabupaten Madiun pada bulan Oktober - November 2020. Objek lokasi penelitian di desa tersebut dipilih berdasarkan pertimbangan bahwasanya Desa Klangon adalah sentral produsen porang di Kabupaten Madiun dan sekaligus endemik porang Indonesia berdasarkan Kementerian Pertanian yang dinamai dengan Madiun-1.

Peneliti memperoleh data langsung dari hasil wawancara, pencatatan dan observasi. Selain itu peneliti juga mengambil data pendukung baik itu data primer melalui pertanyaan-pertanyaan yang diajukan kepada petani, juga hasil survey/observasi. Sedangkan data sekunder bersumber dari kantor desa setempat, Lembaga Masyarakat Desa Hutan (LMDH), instansiinstansi terkait dan berbagai literatur penelitian. Selain itu teknik pengambilan sampel yang akan digunakan adalah menggonakan metode purposive sampling (pengambilan sampel secara sengaja sesuai tujuannya) di Desa Klangon Kecamatan Saradan. Dalam menentukan 
sampel lembaga pemasaran ditentukan dengan menggunakan teknik snowball sampling yaitu mengikuti alur pemasaran dengan menjadikan sampel yang pertama sebagai penentu sampel yang berikutnya.

Dengan menggunakan analisis data deskriptif kualitatif melalui proses reduksi data, penyajian data dan penarikan kesimpulan sehingga penelitian ini dapat menjelaskan tentang dampak usahatani komoditas porang yang dilakukan oleh petani dan sekaligus untuk menjawab mengenai permasalahan dan tujuan tentang kelembagaan dan hasil produksi, pemasaran dan penerimaan serta pendapatan petani di Desa Klangon Kecamatan Saradan Kabupaten Madiun.

\section{Hasil dan Pembahasan}

\section{Analisis Kelembagaan dan Biaya Produksi Komoditas Porang}

Menurut Pusat Penelitian dan Pengembangan Tanaman Pangan (2015), komoditas porang harus ditanam dibawah tegakan hutan. Oleh sebab itu masyarakat desa setempat bekerja sama dengan perhutani melalui Lembaga Masyarakat Desa Hutan (LMDH) dengan menggunakan sistem kerja sama bagi hasil (sharing). Sharing per hektarnya sebesar Rp 1.900 .000 pertahun. Dengan rincian 6\% masuk ke kementerian keuangan dan yang lainnya 94\% masuk ke perhutani.

Dengan luas lahan Hutan Pemangku Desa (HPD) sekitar 1300 Ha, namun lahan yang digarap petani berkisar $585 \mathrm{Ha}$, dan masih bertambah terus hingga $700 \mathrm{Ha}$. Namun demikian yang berproduksi hanya sekitar 247 hektar dengan jumlah produksi satu hektar rata-rata bisa mencapai 6 ton per tahun.

Tabel 1

Biaya Produksi Usahatani Porang

\begin{tabular}{ccc}
\hline Uraian & Ukuran $(\mathrm{Kg} / \mathrm{Ha})$ & Nilai $(\mathrm{Rp} / \mathrm{Ha})$ \\
\hline Bibit Porang & 300 & 75.000 .000 \\
Pupuk & 400 & 960.000 \\
Penyiang Gulma & 10 & 800.000 \\
Tenaga Kerja & 12 & 9.600 .000 \\
Sharing Perhutani & 1 & 1.300 .000 \\
\hline Biaya Produksi & 1 & 87.660 .000
\end{tabular}

Sumber : Olahan Data Primer dan Sekunder, (2020)

Berdasarkan tabel 1 dapat dijelaskan bahwasanya biaya usahatani untuk investasi awal ialah sebesar Rp.87.660.000. Biaya terbesar dikeluarkan untuk pembelian bibit porang (katak) ialah Rp.75.000.000. Biaya tersebut digunakan untuk penanaman satu hektar lahan, yang mana harga katak (bibit porang) tahun 2020 mencapai Rp.300.000 per kilogram pada saat musim tanam. Namun pada awal-awal musim panen mengalami penyusutan harga menjadi Rp.100.000. Dalam investasi awal satu hektar membutuhkan 3 kwintal bibit katak yang kurang lebih dalam satu kilogram isinya 50-60 butir. Biaya terbesar lainnya yaitu sektor tenaga kerja sebesar Rp.9.600.000. Pada saat penanaman dibutuhkan hingga 10 tenaga kerja pada lahan satu hektar. Namun saat perawatan tanaman yang meliputi penyiangan rumput, pemberian pupuk dan penyemprotan lahan dapat dilakukan oleh 2-5 orang selama 2 hari.

Porang bisa dikatakan tumbuhan yang ajaib. Tidak bisa tumbuh disembarang tanah. Harus 
memenuhi syarat dan kriteria tertentu. Porang dapat tumbuh di tanah pegunungan yang gembur dan miring dengan keadaan tegakan hingga 50\%. Selain itu juga harus terkena sinar matahari dan dibawah naungan pepohonan seperti Jati, Mahoni, Sono, Durian dan lain-lain. Namun terlalu banyak pepohonan diatasnya juga tidak bisa membuat porang tumbuh dengan baik.

Selanjutnya yaitu biaya untuk perawatan, yaitu meliputi pemupukan dan penyiangan gulma dengan nilai sebesar Rp.1.760.000. Pupuk yang paling bagus digunakan ialah pupuk ponska dengan harga satu karung (50kg) mencapai Rp.125.000. Pemupukan ini dilakukan sebanyak 2 kali dalam satu tahun. Rata-rata menghabiskan pupuk sebanyak 4 kwintal/tahun. Sedangkan untuk penyiangan memakai penyiang gulma herbisid dengan harga per liternya Rp.80.000. Penyiangan rumput ini memerlukan 10 botol sehingga kisaran harga mencapai Rp.800.000. Urian selajutnya yaitu untuk biaya sharing dengan perhutani atas sewa penggunaan hutan sebesar Rp.1.300.000 per Ha. Biaya tersebut merupakan hasil kesepakatan antara pihak LMDH dengan perhutani. Dengan demikian total biaya produksi untuk usahatani komoditas porang selama satu tahun sebagai investasi awal dengan luas lahan satu hektar adalah Rp.87.660.000.

\section{Analisis Pemasaran Komoditas Porang}

Proses pemasaran porang terdapat beberapa tahapan yang dimulai dari petani, kemudian dikumpulkan ke pengepul, dari pengepul petani (tengkulak) tersebut dikumpulkan ke pedagang pengepul. Setelah itu pedagang pengepul menjualnya ke pabrik atau disetorkan ke beberapa kota, diantaranya Semarang, Surabaya, Bandung, dan lain lain. Selain itu komoditas porang ini juga diekspor ke luar negeri seperti China, Jepang dan Korea dalam bentuk chip (porang kering).

Jaringan pemasaran yang terjadi pada komoditas porang di Desa Klangon ini berjalan secara vertikal dan horizontal. Terdapat dua saluran pemasaran yang berbeda sehingga dapat berpengaruh terhadap penerimaan petani. Komoditas yang dijual atau diperdagangkan ada tiga macam yaitu chip (porang kering), bulbil/katak dan gelondongan (umbi basah).

Dengan mengukur margin pemasaran pada dua saluran diatas, guna mencari saluran pemasaran mana yang lebih menguntungkan terhadap petani. Saluran pemasaran 1 ialah dari Petani - Pedagang Pengepul - Pabrik. Pada pola perdagangan ini petani tidak menjualnya langsung ke pabrik, melainkan dengan melalui perantara pedagang pengepul. Dapat dilihat pada tabel 2 untuk mengetahui marjin dan keuntungan yang diperoleh pihak pengepul pada pemasaran porang.

Tabel 2

Saluran Pemasaran 1 Umbi Porang

\begin{tabular}{|c|c|c|c|c|}
\hline \multirow[b]{2}{*}{ No. } & \multirow[b]{2}{*}{ Keterangan } & \multicolumn{3}{|c|}{ Harga $(\mathrm{Rp} / \mathrm{Kg})$} \\
\hline & & Petani & $\begin{array}{l}\text { Pedagang } \\
\text { Pengepul }\end{array}$ & Pabrik \\
\hline 1 & Harga Beli Umbi & - & 13.000 & 14.714 \\
\hline 2 & Harga Jual Umbi & 13.000 & 14.714 & - \\
\hline 3 & Margin/Keuntungan & - & 1.714 & - \\
\hline
\end{tabular}

Sumber : Olahan Data Primer dan Sekunder, (2020) 
Pada tabel diatas dapat diketahui bahwasanya saluran pemasaran 1, pedagang pengepul menjual umbi porang dengan harga Rp.14.714. Margin pemasaran porang dalam bentuk umbi pada saluran ini ialah sebesar Rp.1.714 per kilogram. Hal tersebut terjadi dikarenakan pedagang pengepul harus mengeluarkan biaya baik itu transport, alat dan lain sebagainya untuk kemudian langsung disetorkan ke pabrik. Selain itu petani komoditas porang juga menjual dalam bentuk chip. Berarti disini petani mengolahnya terlebih dahulu seperti pengrajangan sampai ke penjemuran sebelum dijual ke pedagang pengepul.

Tabel 3

Saluran Pemasaran 1 Chip

\begin{tabular}{ccccc}
\hline & & \multicolumn{3}{c}{ Harga (Rp/Kg) } \\
\cline { 3 - 5 } No. & Keterangan & Petani & $\begin{array}{c}\text { Pedagang } \\
\text { Pengepul }\end{array}$ & Pabrik \\
\hline 1 & Harga Beli Chip & - & 70.000 & 72.444 \\
2 & Harga Jual Chip & 70.000 & 72.444 & - \\
3 & Margin/Keuntungan & - & 2.444 & - \\
\hline
\end{tabular}

Sumber : Olahan Data Primer dan Sekunder, (2020)

Tabel 3 menunjukkan bahwa terjadi perbedaan harga yang sangat signifikan antara penjualan umbi basah (gelondongan) dengan penjualan chip (porang kering). Seperti pada tabel 2 yang menunjukkan bawa harga umbi basah per kilogram yaitu Rp. 13.000. Sedangkan setelah melalui proses pengrajangan, penjemuran atau pengeringan, harga jual bertambah Rp. 57.000 menjadi Rp.70.000 per kilogram seperti tampak pada tabel diatas. Sehingga margin keuntungan pemasaran porang kering chip ini sebesar Rp. 2.444.

Sedangkan pada saluran pemasaran 2 terjadi penambahan lembaga pemasaran baru yaitu tengkulak. Sehingga skemanya menjadi Petani - Tengkulak - Pedagang Pengepul - Pabrik. Fungsi dari tengkulak ini yaitu mengumpulkan hasil produksi dari petani untuk dijual kepada pengepul yang lebih besar, dengan kata lain penjemput bola pada petani.

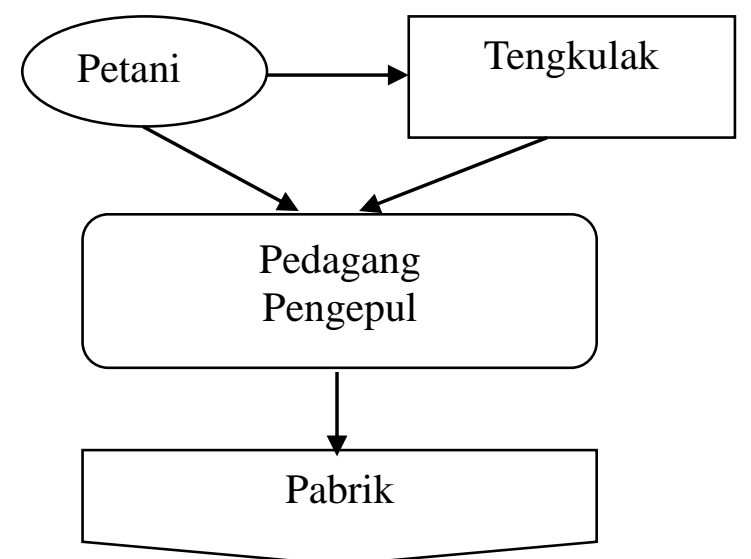

Sumber : Olahan Data Primer, (2020)

Gambar 1

Bagan Saluran Pemasaran Komoditas Porang 
Tabel 4

Saluran Pemasaran 2 Umbi

\begin{tabular}{cccccc}
\hline & & \multicolumn{4}{c}{ Harga $(\mathrm{Rp} / \mathrm{Kg})$} \\
\cline { 3 - 6 } No. & Keterangan & Petani & Tengkulak & $\begin{array}{c}\text { Pedagang } \\
\text { Pengepul }\end{array}$ & Pabrik \\
\hline 1 & Harga Beli Umbi & - & 13.000 & 14.295 & 14.736 \\
2 & Harga Jual Umbi & 13.000 & 14.295 & 14.736 & - \\
3 & Margin/Keuntungan & - & 1.295 & 441 & - \\
\hline
\end{tabular}

Sumber : Olahan Data Primer dan Sekunder, (2020)

Aktivitas pemasaran umbi pada saluran 2 ini sangat berbeda dengan saluran 1. Adanya tengkulak yang men-supply komoditas dari petani sangat berimbas terhadap pendapatan petani juga. Namun hal ini dilakukan karena apabila petani melakukan perdagangan secara langsung acapkali mengalami kesulitan. Dengan adanya hal tersebut mengakibatkan margin keuntungan juga bertambah. Dapat diketahui dari tabel 4 yang menunjukkan bahwasanya margin pemasaran umbi pada saluran 2 ialah sebesar Rp. 1.736. Margin tersebut didapatkan dari margin tengkulak kepada petani sebesar Rp. 1.295 dan kepada pedagang pengepul sebesar Rp. 441. Dari keterangan diatas dengan demikian harga jual umbi dari tengkulak memiliki keuntungan yang lebih besar dibesar. Namun dibandingkan dengan saluran 1, ternyata dengan adanya tengkulak mengakibatkan margin keuntungan pedagang pengepul juga menurun.

Tidak berbeda dengan saluran pemasaran 1. Saluran 2 juga melakukan perdagangan chip (umbi kering). Namun pada saluran 2 ini yang mengolah umbi basah sampai menjadi umbi kering siap jual ialah tengkulak. Hal tersebut dikarenakan umbi kering chip ini harga jualnya sangat mahal bisa 5 kali lipat dari umbi basah yang langsung dijual.

Tabel 5

Saluran Pemasaran 2 Chip

\begin{tabular}{clcccc}
\hline & & \multicolumn{4}{c}{ Harga (Rp/Kg) } \\
\cline { 3 - 6 } No. & \multicolumn{1}{c}{ Keterangan } & Petani & Tengkulak & $\begin{array}{c}\text { Pedagang } \\
\text { Pengepul }\end{array}$ & Pabrik \\
\hline 1 & Harga Beli Chips & - & 70.000 & 71.590 & 72.444 \\
2 & Harga Jual Chips & 70.000 & 71.590 & 72.444 & - \\
3 & Margin/Keuntungan & - & 1.590 & 854 & - \\
\hline
\end{tabular}

Sumber : Olahan Data Primer dan Sekunder, (2020)

Pada penjualan porang dalam bentuk chip memang sangat menguntungkan dibandingkan dengan penjualan dalam bentuk umbi. Dengan harga jual Rp. 70.000 per kilogramnya juga sebanding dengan proses pengolahannya. Margin tengkulak dari petani yang mengolah sendiri chipnya ialah sebesar Rp. 1.590. Dapat juga petani langsung menjualnya kepada tengkulak dengan kondisi umbi basah, namun dengan harga umbi basah satu kilogramnya yaitu Rp.13.000.

Ketika umbi porang sudah dipanen, maka tidak dapat disimpan terlalu lama. Dikarenakan pada bulan 11 yaitu bulan November, umbi tersebut dapat tumbuh begitu saja. Hal tersebut yang menjadikan petani memiliki 2 opsi yaitu untuk langsung menjual dalam bentuk umbi 
basah atau dijadikan chip untuk dijual ke tengkulak atau pedagang pengepul. Sehingga apabila petani menjual umbi basah ke tengkulak, maka pihak tengkulaknya yang melakukan proses pengrajangan hingga penjemuran sampai kering. Sehingga dengan kasus tersebut marjinnya bisa mencapai Rp. 57.000 pada pihak tengkulak. Pedagang pengepul melakukan pembayaran secara lunas dengan menarget jumlah setoran chip tersebut. Jika harga naik maka tengkulak bisa mendapatkan fee dari pedagang pengepul.

\section{Analisis Tingkat Kesejahteraan Petani Komoditas Porang}

Pada tahun 1993-1997 pemerintah Indonesia meluncurkan program penanggulangan kemiskinan dengan memberi bantuan kepada desa-desa tertinggal yang disebut sebagai program IDT (Inpres Desa Tertinggal). Program ini merupakan bagian dari pembangunan pedesaan dengan tujuan utama yaitu meningkatkan kualitas hidup melalui usaha-usaha produktif. (Unggul Priyadi,1997)

\begin{tabular}{|c|c|c|c|}
\hline \multicolumn{4}{|c|}{$\begin{array}{c}\text { Tabel 6 } \\
\text { Rincian Jumlah Penduduk Desa Klangon }\end{array}$} \\
\hline \multicolumn{3}{|c|}{ Jumlah Penduduk } & \multirow{2}{*}{ Jumlah KK } \\
\hline Laki-Laki & Perempuan & Jumlah & \\
\hline 1754 & 1709 & 3463 & 1153 \\
\hline
\end{tabular}

Sumber : Kantor Kepala Desa Klangon, (2020)

Desa Klangon Kecamatan Saradan Kabupaten Madiun dahulunya merupakan salah satu desa dari 1.969 desa di Jawa Timur (Ketua Bappenas, 1994) yang masuk sebagai kategori desa IDT. Saat ini Desa Klangon memiliki jumlah penduduk pada tahun 2020 sebanyak 3463 dan 1153 KK (Kepala Keluarga) dengan 95\% petani di desa ini atau sekitar 1095 KK beralih ke budidaya porang.

Sebelum menanam porang, mata pencaharian di Desa Klangon ini ialah sebagai petani jagung, ketela pohon, dan padi. Tiga komoditas tersebut menjadi keunggulan desa. Setelah adanya porang, komoditas tersebut masih tetap ada, namun mayoritas beralih ke petani porang. Karena sebenarnya porang merupakan tanaman samben yang mana perawatannya itu mudah, namun hasilnya sangat menjanjikan dan dampaknya bagus untuk kesejahteraan desa, sehingga masyarakat desa menjuluki porang sebagai mutiara terpendam.

Setelah dirasa memberikan manfaat terutama untuk pendapatan masyarakat desa, barulah pada tahun 1995 masyarakat Desa Klangon mulai kompak dalam membudidayakan tanaman ini. Dilakukan penataan lahan dan diberi kuota per rumah atau KK maksimal yaitu 2 Ha. Jadi setiap KK atau keluarga mempunyai lahan sendiri dengan bekerja sama (sharing) bagi hasil dengan perhutani guna mencapai kesejahteraan bersama.

\section{Tabel 7}

Luas Wilayah Desa Klangon

\begin{tabular}{cc}
\hline \multicolumn{2}{c}{ Luas Wilayah (Ha) } \\
\hline Pemukiman & 290.660 \\
Sawah & 105.677 \\
Ladang & 120.03 \\
\hline Hutan & 1.141 .765
\end{tabular}

Sumber : Kantor Kepala Desa Klangon, (2020) 
Dengan didukung dengan luas hutan sebesar 1.414.765 Ha dan sekaligus berada di keadaan topografi desa yang merupakan daerah pegunungan menjadi salah satu pendorong pembudidayaan tanaman porang hingga berpotensi meningkatkan permintaan komoditas porang. Dengan adanya komoditas porang, pekonomian masyarakat bisa meningkat. Dibuktikan saat musim panen antara bulan mei sampai september atau dikenal dengan (panen raya). Panen raya konsepnya tidak panen bersama-sama dalam satu hari, tetapi tergantung kebutuhan masing-masing petani. Jadi walaupun panen raya, tidak serta-merta berlangsung secara bersama-sama seluruh desa. Tatkala butuh uang berarti petani harus panen terlebih dahulu. Sehari paling tidak ada 10-15 petani. Dalam panen tersebut petani dapat menghasilkan per hektarnya 5 ton - 10 ton. Dengan satu umbi porang bisa mencapai satu kilo lebih. Dan perkilo umbinya dihargai sebesar Rp. 13.000. Jadi saat musim panen, perekonomian masyarakat setempat dapat berputar dengan baik.

Untuk hasil panen porang tidak bisa langsung banyak, dikarenakan menggunakan sistem panen pilih. Satu hektar jikalau ditanami dengan jangka waktu 3 tahun, maka apabila dipanen semua bersih bisa dapat 10 ton. Tapi nanti tumbuhan porangnya akan habis dan harus menanam dari awal lagi. Untuk mensiasati hal tersebut diterapkanlah sistem tebang pilih. Dengan sistem ini tidak semuanya dipanen, namun hanya dipilih untuk umbi yang besar-besar saja, sehingga sekali menanam bisa dipanen bertahun-tahun. Dalam artian sekali tanam bisa menjadi investasi untuk selamanya. Karena dari daunnya porang itu terdapat bulbil katak dan untuk satu pohon bisa sampai 40-50 bulbil katak. Harga jual bibit katak per satu kilogramnya pun dihargai sebesar Rp. 300.000. Jadi ketika petani ingin memanen umbi yang dibawah, maka petani sudah memiliki keuntungan dari katak/bulbil. Bulbil katak tersebut nantinya digunakan juga sebagai bibit atau dapat dijual. Selain dijual ada juga yang ditanam untuk perluasan lahan. Jika tahun ini satu hektar maka untuk tahun depan bisa melakukan perluasan hingga 2 hektar.

Dari usahatani porang ini sekaligus bisa membuka lapangan kerja baru, sebab petani Desa Klangon sangat kekurangan tenaga kerja untuk melakukan penanaman, perawatan, pemanenan dan sebagainya. Sehingga di-supply dari daerah Bojonegoro, Nganjuk, Klino, Ngawi dan lain lain. Hal tersebut terjadi karena petani mempunyai lahan sendiri-sendiri, sehingga harus mencari tenaga kerja dari luar daerah.

\section{Tabel 8}

Tingkat Kesejahteraan Rakyat Desa Klangon

\begin{tabular}{ccc} 
Tingkat Kesejahteraan Rakyat & Persentase \\
(KK/Jiwa) & $23 \%$ \\
\hline Kaya & 266 KK / 707 Jiwa & 26\% \\
Sedang & $472 \mathrm{KK} / 1652$ Jiwa & $40,9 \%$ \\
RTM & $415 \mathrm{KK} / 1104$ Jiwa & $35,9 \%$
\end{tabular}

Sumber : Kantor Kepala Desa Klangon, (2020)

Tingkat kesejahteraan yaitu tingkatan kondisi seseorang atau masyarakat yang telah terpenuhinya kebutuhan dasar berupa sandang, pangan, papan, kesehatan, lapangan pekerjaan, pendidikan, dan kebutuhan lainnya seperti lingkungan bersih, aman dan nyaman, terpenuhinya hak asasi dan partisipasi serta terwujudnya masyarakat yang beriman dan bertaqwa (Kementerian Koordinator Kesejahteraan Rakyat).

Pada tabel 7 diatas dapat diketahui bahwasanya tingkat kesejahteraan masyarakyat Desa Klangon mayoritas yaitu sedang, dengan persentase 40,9\%. Namun secara keseluruhan 
jumlah menengah keatas lebih banyak dibandingkan dengan jumlah menengah ke bawah dengan proporsi $63,9 \%$ berbanding $35,9 \%$ atau sebanyak 738 KK yang dalam kriteria menengah keatas.

\section{Penerimaan dan Pendapatan Petani Porang}

Dari hasil penelitian menunjukkan bahwa usahatani komoditas porang di Desa Klangon Kecamatan Saradan Kabupaten Madiun ini dapat berkembang dengan sangat baik. Hal tersebut dapat terlihat dari banyaknya masyarakat yang semula bermata pencaharian sebagai petani padi, jagung, ketela, dan lain-lain, berpindah haluan menjadi petani porang. Komoditas porang ini menjadi salah satu komoditi ekspor unggulan di Desa Klangon dan menjadi tempat endemik porang Indonesia. Dengan luas lahan $585 \mathrm{Ha}$ dan masih bertambah hingga $700 \mathrm{Ha}$ menjadi peluang ekonomi untuk meningkatkan produksi dan pendapatan yang lebih besar. Karena luas lahan gaparan menjadi faktor utama yang mempengaruhi tingkat produksi dan penerimaan petani (Hernanto, 1996).

Tabel 9

Rincian Total Penerimaan Petani Porang

\begin{tabular}{cc}
\hline Produksi & Nilai \\
\hline Umbi & \\
Umbi Porang $(\mathrm{Kg})$ & 6000 \\
Harga $(\mathrm{Rp} / \mathrm{Kg})$ & 13.000 \\
Total $(\mathrm{Rp})$ & 78.000 .000 \\
Bulbil & \\
Bulbil $(\mathrm{Kg})$ & 1000 \\
Harga $(\mathrm{Rp} / \mathrm{Kg})$ & 270.000 \\
Total $(\mathrm{Rp})$ & 270.000 .000 \\
\hline Total Penerimaan & $\mathbf{R p 3 4 8 . 0 0 0 . 0 0 0}$
\end{tabular}

Sumber : Olahan Data Primer, (2020)

Berdasarkan tabel diatas rata-rata penerimaan usahatani porang secara keseluruhan ialah Rp. 348.000.000 per Ha per Tahun. Produksi umbi porang dalam satu hektar rata-rata 6 ton. Dengan kisaran produksi tertinggi ialah 10 Ton per Ha per Tahun, sedangkan untuk kisaran terendah ialah 3 Ton per Ha per Tahun. Dengan harga jual per kilogram umbinya ialah antara Rp. 13.000 hingga Rp. 13.500.

Sedangkan untuk harga umbi daun/katak/bulbil senilai Rp. 200.000 - 300.000/kg. Pada awalawal musim panen kisaran harga katak ini hanya dihargai Rp.100.00/kg. Namun saat musim tanam, harganya bisa menyentuh angka Rp.320.000/kg. Bulbil ini juga dimanfaatkan sebagai bahan tanam (bibit). Dalam 1 kali panen rata-rata petani memperoleh 1 kwintal atau $1000 \mathrm{~kg}$ dengan 1kgnya berisi 50 - 80 butir biji ukuran besar dan 400 butir untuk ukuran kecil.

Produksi porang yang tinggi dapat memberikan penerimaan yang tinggi pula terhadap petani. Tingkat produksi juga dipengaruhi oleh faktor produksi yang digunakan, baik dalam hal jumlah maupun kualitas. Dengan produksi komoditas yang besar maka akan menentukan besarnya kesempatan ekonomi yang diterima petani. Apabila tingkat produksi yang diperoleh petani tinggi, maka arus kesempatan ekonomi yang diperoleh cukup besar dan sebaliknya. (Mubyarto, 1991). Oleh karena itu pendapatan petani porang yang diterima dapat digunakan 
untuk memenuhi kebutuhan hidup sehari-hari, sehingga meningkatkan kesejahteraan masyarakat. Sebab sebuah keberhasilan usahatani ialah dilihat dari pendapatan yang diperoleh. Pendapatan diartikan sebagai selisih antara besarnya penerimaan dan biaya yang dikeluarkan. Pendapatan usahatani porang ini dihitung dari jumlah produksi dikalikan dengan harga jual (penerimaan) dan kemudian dikurangi dengan jumlah biaya-biaya yang dikeluarkan selama proses produksi berlangsung.

\section{Tabel 10}

Pendapatan Usahatani Porang

\begin{tabular}{cc}
\hline \multicolumn{2}{c}{ Pendapatan/Ha } \\
\hline Total Penerimaan & Rp348.000.000 \\
Biaya Produksi & Rp87.660.000 \\
\hline Hasil & Rp260.340.000
\end{tabular}

Sumber : Olahan Data Primer, (2020)

Pada tabel diatas menunjukkan hasil dari pendapatan petani pertahunnya yaitu sebesar Rp. 260.340.000. Pendapatan tersebut diperoleh dari penjualan katak/bulbil dan juga dari umbi porang. Dengan demikian usahatani porang di Desa Klangon ini sungguh layak untuk dikembangkan. Terlebih lagi bukan hanya Desa Klangon saja, melainkan untuk masyarakat pinggiran hutan di wilayah manapun seyogyanya menanam porang. Melihat porang ini sesuatu bahan pangan yang belum tercukupi dalam lingkup skala nasional maupun global.

\section{Dampak Positif Dan Negatif Porang Terhadap Kesejahteraan Masyarakat Desa}

Dampak dari budidaya porang bagi masyarakat Desa Klangon, Kecamatan Saradan, Kabupaten Madiun, memang sungguh luar biasa menjanjikannya. Pasalnya, pada tahun 1980an Desa Klangon termasuk Desa IDT (Inpress Desa Tertinggal). Dimana masyarakat desa mempunyai pekerjaan yang hanya cukup untuk makan saja. Namun demikian setelah adanya usahatani porang, masyarakat sudah bisa mandiri secara ekonomi. Sudah hampir 95\% warga desa menanam porang, mulai dari anak muda sampai yang sudah berumah tangga sudah mempunyai lahan porang yang dibudidayakan sendiri. Sehingga berkaitan dengan dampak positif porang terhadap kesejahteraan masyarakat bisa diamati dari dominannya komoditi ini sebagai tulang punggung warga desa terkait untuk kebutuhan financial yang mana komoditi yang lain, seperti padi, jagung, yang hanya sebagai tanaman untuk penyediaan makanan.

Potensi budidaya porang sangat besar bagi masyarakat di Desa Klangon Kecamatan Saradan Kabupaten Madiun sebagai mata pencaharian masyarakat desa setempat dengan memanfaatkan lahan hutan sebagai tempat budidaya tanaman porang. Nilai kesejahteraan masyarakat desa pun akibat usahatani porang ini hampir di angka 63,9\%. Jadi masyarakat Desa Klangon sudah betul-betul menekuni usahatani porang ini sehingga kesejahteraan tiap individu keluarga sudah tercukupi dengan baik. Bahkan masyarakat desa menganggap porang sebagai mutiara terpendam. Terlebih lagi porang sudah masuk dalam ketahanan pangan sehingga sendi-sendi kehidupan masyarakat desa setempat tidak bisa terlepas dari adamya budidaya porang.

Dengan adanya usahatani porang ini sekaligus dapat menguatkan ekonomi pedesaan terkait kebutuhan financial untuk kebutuhan tersier. Dengan rincian pendapatan petani untuk luas lahan satu hektar bisa ialah sebesar Rp. 260.340 .000 selama satu tahun, maka dampak ekonomi yang cukup tinggi tersebut menjadikan petani porang sangat sejahtera, khususnya bagi masyarakat sekitar hutan atau PHBM (Pengelolaan Hutan Bersama Masyarakat). Porang juga membutuhkan waktu yang lama untuk bisa turun harga jualnya, mengingat bahwa porang 
merupakan bahan pangan ekspor untuk makanan sehat berbasis karbohidrat.

Sedangkan untuk dampak negatif tidak ditemukan pada budidaya porang ini terlebih lagi terhadap kesejahteraan masyarakat desa. Namun, dalam budidaya porang, lama umur tanam porang bisa mencapai 3 tahun, hal tersebut merupakan kelemahan khususnya dalam permodalan awal, karena baru menikmati hasil panennya nanti dalam tahun ke 4 . Sebagai alternatif solusi guna mempertahankan kelangsungan hidup petani, kondisi tersebut sangat memperlukan menajemen pembudidayaan yang baik untuk mengatasi agar petani punya pendapatan lain selama 3 tahun tanaman porang belum menghasilkan pada awal penanaman. Penanaman porang ini juga tidak bisa dilakukan di sembarang tempat, sebab harus terdapat naungan pohon kayu diatasnya sehingga perlu memperhatikan sistem hutan seperti tegakan dan tanaman penyangganya.

Selain itu, petani Desa Klangon dalam pengembangan porang juga dihadapkan dengan berbagai masalah mulai dari keterbatasan lahan akibat besarnya kemauan masyarakat akan budidaya porang, hingga masalah subsidi pupuk dan bibit pada awal investasi menanam. Dengan permasalahan tersebut, LMDH Desa Klangon berupaya untuk mengembangkan strategi dalam budidaya porang, antara lain dengan menggunakan sistem penanaman profesional, memakai pupuk-pupuk stimulan, penggunaan dan pembiasaan diri menggunakan pupuk non subsidi, serta pelarangan untuk ekspor bibit porang agar perkembangbiakan porang tidak dikuasai oleh negara lain. Dari berbagai upaya tersebut, dimaksudkan untuk memaksimalkan produksi porang di Desa Klangon Kecamatan Saradan Kabupaten Madiun. Oleh karena itu dengan budidaya porang dengan sistem pemeliharaan yang baik, sehingga kualiatas porang juga semakin bagus dan dampak dari lingkungan terutama lahan hutan juga semakin produktif.

\section{Kesimpulan}

Berdasarkan penelitian ini dapat disimpulkan bahwa dilihat dari kelembagaan dan biaya produksi, pemasaran dan penerimaan serta pendapatan petani yang menunjukkan bahwa dampak usahatani komoditas porang terhadap kesejahteraan masyarakat di Desa Klangon, Kecamatan Saradan, Kabupaten Madiun sangat besar dan layak untuk dikembangkan. Ditinjau dari tingkat kesejahteraan rakyat Desa Klangon mayoritas yaitu sedang, dengan persentase 40,9\%. Namun demikian secara keseluruhan jumlah menengah keatas lebih banyak dibandingkan dengan menengah ke bawah dengan proporsi $63,9 \%$ berbanding $35,9 \%$ atau sebanyak $738 \mathrm{KK}$ yang dalam kriteria menengah keatas. Komoditas yang dijual atau diperdagangkan ada tiga macam yaitu chip (porang kering diolah), bulbil katak dan gelondongan (umbi basah). Untuk pemasarannya, petani dapat menggunakan saluran pemasaran 1 dengan skema dari Petani - Pedagang Pengepul - Pabrik. Pada pola perdagangan ini petani tidak menjual melalui tengkulak, melainkan dengan melalui perantara pedagang pengepul. Sehingga saluran pemasaran dapat dipangkas dan marjin penjualan yang diperoleh petani bisa lebih banyak. Daftar harga jual chip per kilogramnya ialah Rp. 70.000, harga jual katak (bibit porang) mencapai Rp. 300.000 per kilogram, sedangkan untuk harga umbi basah per kilogram yaitu Rp. 13.000. Berdasarkan keterangan diatas rata-rata penerimaan usahatani porang secara keseluruhan ialah Rp. 348.000.000 per Ha per Tahun dengan biaya produksi awal (investasi awal) untuk usahatani komoditas porang selama satu tahun dengan luas lahan satu hektar ialah Rp.87.660.000. Sehingga pendapatan petani porang dalam satu tahun mencapai Rp.260.340.000. Dengan rincian tersebut maka dampak ekonomi yang cukup tinggi menjadikan petani porang sangat sejahtera, khususnya bagi masyarakat sekitar hutan atau PHBM (Pengelolaan Hutan Bersama Masyarakat). Dengan demikian yang mulanya pada tahun 1980-an Desa Klangon termasuk Desa IDT (Inpress Desa Tertinggal). Namun sekarang masyarakat sudah bisa mandiri secara ekonomi setelah adanya usahatani porang. Bahkan 
masyarakat desa menganggap porang sebagai mutiara terpendam. Terlebih lagi porang sudah masuk ke ketahanan pangan sehingga sendi-sendi kehidupan masyarakat desa setempat tidak terlepas dari budidaya porang. Dengan melihat potensi dan besarnya peranan usahatani porang ini terhadap perekonomian masyarakat Desa Klangon, untuk itu perlu adanya campur tangan Pemerintah Kabupaten Madiun dan Perhutani guna melakukan pemilihan lokasi baru yang cermat untuk budidaya porang dengan memperhatikan prasyarat tumbuh dan iklimnya, juga perlu adanya peningkatan investasi pada komoditas tersebut karena mengingat masih sangat memungkinkan untuk ditingkatkan. Serta pemerintah dalam hal ini Dinas Pertanian dan Perikanan Kabupaten Madiun harus konsen melalui subsidi pupuk kepada petani porang. Sedangkan untuk petani porang sendiri alangkah lebih baiknya menjual komoditas porang dalam bentuk chips, karena lebih memiliki nilai tambah dan lebih besar penerimaannya dibandingkan dengan dijual dalam bentuk umbi. Petani juga perlu mengembangkan budidaya tanaman porang secara organik sehingga permasalahan subsidi pupuk dapat teratasi.

\section{Ucapan Terimakasih}

Pada penelitian ini penulis menyampaikan terima kasih kepada Bapak Achmad Room Fitrianto, Ph.D yang telah membimbing sekaligus memberikan nasehat serta arahan sehingga penelitian ini dapat terlaksana dengan baik. Selain itu ucapan terimakasih juga dihaturkan kepada Kepala Desa Klangon, Ketua LMDH serta Bapak Kepala Dusun Desa setempat yang telah berkenan untuk diwawancarai dan memfasilitasi pelaksanaan penelitian di lapangan.

\section{Daftar Pustaka}

Anggraini Riska, Rosyani, F. A. (2015). Dampak Usahatani Kebun Kelapa Sawit Terhadap Kesejahteraan Masyarakat Di Desa Merlung Kecamatan Merlung Kabupaten Tanjung Jabung Barat. Sosio Ekonomika Bisnis, 18(2), 11-24.

Arafia, I. A., Syakir, I. F., \& Arifin, I. Z. (2020). Kelembagaaan Pemasaran Dan Usahatani Porang Di Kecamatan Saradan Kabupaten Madiun. Jurnal Sosial Ekonomi Pertanian Dan Agribisnis (Seagri), 1(4), 239-111.

Dinas Pertanian Dan Perikanan Kabupaten Madiun. (2019). Laporan Kinerja Tahun 2019. Kabupaten Madiun.

Fadholi Hermanto. (1996). Ilmu Usahatani. Jakarta: Penebar Swadaya.

Faridah, A., Widjanarko, S. B., Sutrisno, A., \& Susilo, B. (2009). Optimasi Produksi Tepung Porang Dari Chip Porang Secara Mekanis Dengan Metode Permukaan Respons. Teknik Industri, 12(2), 155-166.

Mubyarto. (1991). Pengantar Ekonomi Pertanian. Jakarta: Lp3es.

Mutmaidah, S., \& Rozi, F. (2015). Peluang Peningkatan Pendapatan Masyarakat Tepi Hutan Melalui Usahatani Porang. Prosiding Seminar Hasil Penelitian Tanaman Aneka Kacang Dan Umbi 2015, (Dephut 2009), 709-716.

Padusung, Fahrudin, Mahrup, Kusnanta, I., \& Soemeinaboedhy. (2020). Seminar Nasional Karya Pengabdian Meningkatkan Kesejahteraan Petani Hutan Melalui Integrasi Tanaman Porang ( Amorphophallus Onchophyllus ) Dengan Vegetasi Tegakan Di Kawasan Rinjani Lombok. Mataram.

Priyanto, E., Sukaryorini, P., \& Prabowo, B. (2016). Pemetaan Potensi Tanaman Porang Sebagai Komoditas Ekspor. 5(2), 1-18.

Purwanto, A. (2014). Pembuatan Brem Padat Dari Umbi Porang (Amorphophallus Oncophyllus Prain. Widya Warta, (01), 16-28. 
Rofik, K., Setiahadi, R., Puspatiwati, I. R., \& Lukito, M. (2017). Potensi Produksi Tanaman Porang (Amorphophallus Muelleri Blume) Di Kelompok Tani Mpsdh Wono Lestari Desa Padas Kecamatan Dagangan Kabupaten Madiun. Agri-Tek, 17(September), 53-65.

Saleh, N., Rahayuningsih, S. ., Radjit, B. S., Ginting, E., Harnowo, D., \& Mejaya, I. M. J. (2015). Tanaman Porang; Pengenalan, Budidaya, Dan Pemanfaatannya (A. Winarto, Ed.). Bogor: Pusat Penelitian Dan Pengembangan Tanaman Pangan Badan Penelitian Dan Pengembangan Pertanian.

Sari, R., \& Suhartati. (2015). Tumbuhan Porang: Prospek Budidaya Sebagai Salah Satu Sistem Agroforestry. Info Teknis Eboni, 12(2), 97-110.

Unggul, P. (1997). Pelaksanaan Program Inpres Desa Tertinggal Dalam Perspektif Pembangunan Perdesaan. Jep, 2(3), 290-300.

Wahyono, A., Arifianto, A. S., \& Wahyono, N. D. (2017). Prospek Ekonomi Kebijakan Pemanfaatan Produktifitas Lahan Tidur Untuk Pengembangan Porang Dan Jamur Tiram Di Jawa Timur. Jurnal Cakrawala, 11(2), 171-180. 